\title{
Aspirin and salicylate in respiratory disease *
}

\author{
James E. Mitchell1,2, Isabel Skypala ${ }^{3}$ \\ 'Department of Ear Nose and Throat Surgery, Royal Surrey County Hospital NHS Foundation Trust, Guildford, United Kingdom
2 'University of Southampton Allergy Research \& Postgraduate Academic Unit, Southampton General Hospital, Southampton, \\ United Kingdom \\ ${ }^{3}$ Rehabilitation and Therapies, Royal Brompton and Harefield NHS Foundation Trust, London, United Kingdom
}

Rhinology 51: 195-205, 2013

DOI:10.4193/Rhino12.144

*Received for publication:

August 29, 2012

Accepted: April 7, 2013

\section{Summary}

This article describes the natural history, pathogenesis and diagnosis of Aspirin Exacerbated Respiratory Disease. The evidence base for the role of oral aspirin and nasal L-Lysine-aspirin desensitisation is reviewed. Evidence for the role of dietary salicylic acid and its avoidance is also reviewed.

Key words: asthma, aspirin, aspirin desensitisation, chronic rhino-sinusitis, salicylate

\section{Introduction}

Aspirin Exacerbated Respiratory Disease (AERD) is an aggressive mucosal inflammatory disease affecting the upper and lower airways, precipitated after the ingestion of aspirin and most non-steroidal anti-inflammatory drugs (NSAIDs) ${ }^{(1)}$. It results in significant patient morbidity and treatment costs ${ }^{(1,2)}$. Estimates of AERD prevalence vary with the population studied and diagnostic methodology. Twenty-one percent of asthmatics on oral provocation testing have AERD. Using history alone, prevalence falls to $2.7 \%{ }^{(3)}$. AERD is more prevalent in patients with more severe airway disease; $0.7 \%-1.4 \%$ of those with non-allergic rhinitis alone compared with $30-42 \%$ of those with nasal polyps and abnormal sinus CT scans ${ }^{(4,5)}$.

\section{Natural history of AERD}

AERD is virtually only seen in adulthood and the symptoms develop in a typical sequence ${ }^{(6,7)}$. Persistent rhinitis occurs initially at a mean age of $29.7 \pm 12.5$ years. This is usually perennial, difficult to treat and characterised by watery rhinorrhoea, nasal block and sneeze with $55 \%$ of patients developing anosmia. Asthma then typically develops two years later (precipitated by
URTI in $45 \%$ or NSAID use in $14 \%$ ). On average four years later, nasal polyps are evident in $60 \%$ of patients and a clear history of NSAIDs exacerbating symptoms becomes apparent. Females are more commonly affected (2.3:1 F:M ratio) and typically have more severe disease occurring at a younger age. Reactions to NSAIDs include: dyspnoea in $88 \%$, nasal discharge and blockage in $42 \%$, skin manifestations in $20 \%$, conjunctival irritation in $15 \%$, angio-oedema in $8 \%$ and anaphylaxis in $6 \%$. A positive family history is present in $6 \%$ and $34-64 \%$ have positive skin prick test (SPT) of one or more common aero-allergen. In those with positive SPT, rhinitis and asthma typically occurs 6-7 years earlier. In a cohort of severe AERD patients referred for AD, 99\% had nasal polyps and $94 \%$ had previously undergone sinus surgery ${ }^{(7)}$.

\section{Disease pathogenesis}

The clinical reaction of these patients to NSAID ingestion resembles an immediate hypersensitivity reaction, however an $\lg \mathrm{E}$ - antigen mechanism has never been demonstrated in AERD. AERD is more likely to be associated with abnormalities in arachidonic acid (AA) metabolism (Figure 1). Phospholipids 


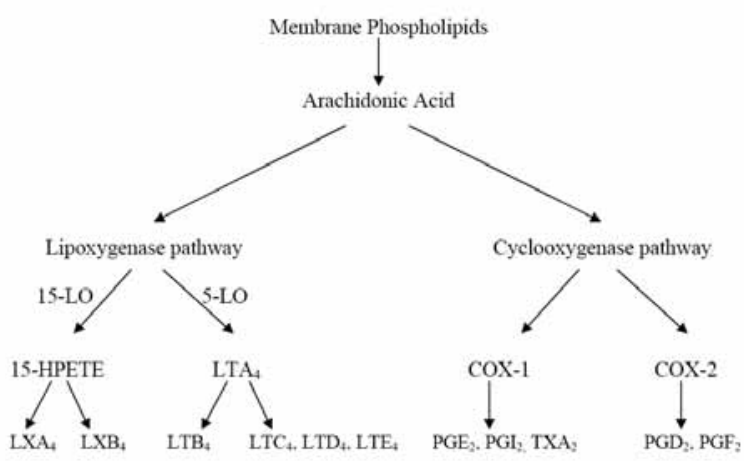

Figure 1. Arachidonic acid metabolic pathway.

are normally broken down into AA in cell membranes. Under normal conditions, AA is metabolised to Prostaglandin E2, I2 and thromboxanes via cyclo-oxygenase (COX1). COX1 is expressed in most mammalian cells. COX2 is induced mainly during inflammation. Under inflammatory conditions metabolites include PGD2 and PGE2. AA is also metabolised via a second pathway; the lipoxygenase pathway. The products of this pathway include LTA4 and 15-HPETE. These are further metabolised into pro-inflammatory mediators such as LTC4, LTD4 and LTE4. Lipoxins are also important products of the lipoxygenase pathway. Lipoxins act as anti-inflammatory mediators.

AERD patients have high levels of inflammatory mediators. Nasal and bronchial biopsy specimens from AERD patients demonstrate extensive infiltration of eosinophils and degranulated mast cells ${ }^{(8)}$. The epithelial cells also show increased levels of Th2 lymphocytes and pro-inflammatory cytokines ${ }^{(9)}$. However, these findings are also seen in non-AERD asthmatic / rhinosinusitis patients. Most AERD patients however synthesise excessive leucotrienes, even before exposure to aspirin ${ }^{(10)}$. Higher concentrations of cys-LTs are found in urine, sputum, blood and breath from AERD patients compared with asthmatics and healthy controls ${ }^{(11)}$. Many also demonstrate overexpression of LTC4-synthase in mast cells and eosinophils and their circulating eosinophils contain more mRNA for LTC4-synthase ${ }^{(12)}$. AERD patients also have raised cysLT1 receptors ${ }^{(13)}$. Pro-inflammatory PGD2 is also overproduced in AERD patients ${ }^{(14)}$.

AERD patients also demonstrate underproduction of anti-inflammatory factors like lipoxins and PGE2 ${ }^{(15)}$. In one study, single nucleotide polymorphisms in the promotor region of the gene encoding the PGE2 receptor EP2 were significantly associated with AERD ${ }^{(16)}$. Reduced EP2 might disable these patients from inhibiting 5-Lipoxygenase which would reduce anti-inflammatory lipoxin levels.

NSAIDs rapidly bind COX1 resulting in a decrease in COX1 products such as PGE2. PGE2 bronchodilates and inhibits 5-Lipoxy- genase. Therefore, on a background of lower PGE2 in AERD, a higher shift towards pro-inflammatory cytokines occurs. These patients are more sensitive to this increase, given their elevated cysLT1 receptor counts.

It is still unclear why AERD patients should develop these pathway anomalies. Theories include viral induction of Th2 lymphocytes in genetically susceptible individuals ${ }^{(17)}$, but this has never been conclusively proven. What is well established now is that AERD patients have a variety of defects in overproduction of inflammatory or underproduction of anti-inflammatory factors. All these anomalies result in rendering these patients vulnerable to COX1 inhibitors and more severe airways disease.

\section{Dietary sources of salicylic acid}

Aspirin is a pro-drug. After absorption from the gastro-intestinal tract, it is rapidly hydrolysed to the active metabolite salicylic acid which is widely distributed in body tissues. Salicylic acid is also widely distributed in plant foods and has anti-pathogenic activity. There has been much interest in the properties of natural salicylates; willow and meadowsweet were used in ancient times to treat fevers and pain, and it is suggested that their effectiveness is due to their high salicylic acid content ${ }^{(18)}$. More recently, the high content of salicylates in curry spices has been proposed as having a protective effect against colorectal cancer in the Indian population ${ }^{(19,20)}$.

The role of dietary salicylates in the aetiology of adverse reactions to foods first came to prominence in the 1960s and 1970s, with a plethora of published studies mainly proposing a link between dietary salicylate and urticaria ${ }^{(21-23)}$. Links between salicylates and asthma were usually made as a consequence of studies on aspirin and asthma ${ }^{(24)}$. However, unlike aspirin, non-acetylated salicylates have no effect on COX1, and although they have been shown to inhibit COX2 gene expression ${ }^{(25,26)}$, the evidence of the role of salicylic acid in aspirin-sensitive asthma from intervention studies is contradictory ${ }^{(27,28)}$.

A review by Baenkler in 2008 suggested that the classical symptoms of salicylate sensitivity occur in the respiratory tract, with manifestations including rhinosiusitis, nasal polyps and asthma ${ }^{(29)}$. Aspirin triad disease was first reported in 1922, but characterised by Samter and Beers in 1967 as a non-immunologic systemic disease ${ }^{(30)}$. Baenkler proposes that up to $2.5 \%$ of Europeans may be affected by dietary salicylate, and $10 \%$ of those with intrinsic asthma. Since COX2 expression is down-regulated in nasal polyps from AERD patients ${ }^{(31)}$, it may be logical to assume that such patients may be more likely to be affected by dietary salicylate. Unfortunately there have been no published studies on the efficacy of restricting dietary salicylate in patients with nasal polyps, asthma or Samter's triad. This could be due to the contradictory nature of the published data on the 
salicylate content of foods ${ }^{(32-35)}$. A review by Janssen showed that, in addition to different analytical methods, the amount of salicylic acid could vary due to a multiplicity of factors including differences in origin, production methods and storage of the food ${ }^{(36-38)}$. Certain foods such as herbs and spices are rich sources of dietary salicylate; Paterson et al. showed that a portion of vindaloo curry could contain as much as $94 \mathrm{mg}$ of salicylic acid and that the salicylate content of blood and urine was shown to increase following consumption of the meal, indicating that this dietary source of salicylic acid was bioavailable ${ }^{(39)}$. Interestingly, it has been shown that curry sauce inhibits both COX 1 and COX2, which may indicate it could be a more important dietary factor than other salicylate-containing foods which may only inhibit $\operatorname{COX} 2^{(40)}$. The evaluation of levels of salicylate metabolites in plasma and urine have also given conflicting results ${ }^{(35)}$; Janssen and colleagues reported that urinary salicylate excretion showed that the bioavailability of dietary salicylate in most people is low ${ }^{(41)}$. However, a more recent study reported that vegetarians have much higher levels of salicylate metabolites, indicating they could be consuming enough dietary salicylate to be equivalent to taking $75 \mathrm{mg}$ aspirin a day ${ }^{(42)}$.

\section{Diagnosis of salicylate intolerance \& AERD}

Most patients with suspected AERD will be diagnosed on history alone of prompt exacerbation of asthma, rhinitic symptoms or even anaphylaxis after ingestion of aspirin / COX1 inhibitors. If foods are reported to exacerbate these symptoms, the physician will need to consider the balance of probabilities as to whether these symptoms are provoked by the natural salicylate in foods. It is also very important not to rule out the possibility of IgEmediated food allergy in this instance, and test for this before implementing dietary restrictions. Due to the lack of good evidence as to the efficacy of low salicylate diets, any dietary diagnostic approach should be approached with caution. If a low salicylate diet is proposed, it must always be time-limited and rigorously monitored as to its effectiveness in controlling symptoms.

\section{Diagnostic tests}

Although much research has been undertaken to improve the diagnosis of AERD, no specific in vitro test is used exclusively for diagnosis. Provocation testing remains the only useful test ${ }^{(43)}$. Table 1 summarises diagnostic approaches and their relative disadvantages / advantages. Oral challenge is currently considered the gold standard for respiratory and cutaneous reactions thought to be due to COX1 inhibitors / salicylate. Nasal provocation testing with L-lysine-aspirin (which is poorly absorbed) may overcome the not insignificant group of patients who have severe reactions on oral challenge ${ }^{(44)}$.

Current diagnostic guidelines

In 2007, EAACl /GA²LEN published guidelines for testing proto- cols ${ }^{(47)}$.

Oral aspirin challenge, bronchial L-ASA challenge or nasal L-ASA challenge may be used in AERD diagnosis. These are performed as single blind placebo controlled challenges. The guidelines advise on safety measures such as access to resuscitation facilities and ensuring the patient is stable pre-challenge (e.g. baseline $\mathrm{FEV}_{1}$ should be $>70 \%$ of predicted). Contraindications to oral challenge include previous anaphylaxis to NSAIDs (consider nasal challenge in these cases), severe cardiac / gastro-intestinal or renal disease, recent URTI, pregnancy and current use of beta blockers.

The challenge is performed over two days. Day one ensures

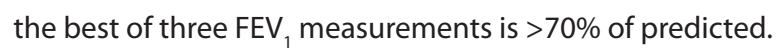
Three placebo capsules are administered at 1.5-2 hour intervals and $\mathrm{FEV}_{1}$ is measured every 30 mins. If $\mathrm{FEV}_{1}$ varies more than $15 \%$ from baseline, then the patient is deemed too unstable to proceed with challenge. On day two, baseline FEV $\mathrm{F}_{1}$ is checked to be $>70 \%$ of predicted and four exponentially increasing doses (e.g 27, 44, 117, $312 \mathrm{mg}$ ) of aspirin are administered every 1.5-2 hrs until a cumulative dose of $500 \mathrm{mg}$ is reached. $\mathrm{FEV}_{1}$ and symptoms (bronchial, nasal, ocular, skin, gastrointestinal, etc.) are recorded every 30 mins. A positive reaction occurs if $\mathrm{FEV}_{1}$ falls $>20 \%$ from baseline or severe extra-bronchial symptoms occur.

Nasal aspirin challenge can be used in patients in whom oral or bronchial challenge is contraindicated. The patient is required to withdraw various treatments which may influence the challenge (e.g. steroids, anti-histamines, LTRAs, etc.). The patient is challenged with placebo (saline drops) and any reaction assessed (either clinical symptoms, acoustic rhinometry, active anterior rhinomanometry or peak nasal inspiratory flow). The patient is assessed every 10 mins over the next half hour. If no reaction occurs, then $80 \mu \mathrm{l}$ of L-ASA is placed into each nostril. Assessments are made every 10 mins for $2 \mathrm{hrs}$ (or three hrs if reaction occurs). A positive reaction is defined as development of symptoms, $25 \%$ decrease in total nasal flow at $12 \mathrm{~cm}$ compared to baseline on acoustic rhinomanometry or $40 \%$ drop of inspiratory nasal flow. The group recommend that a negative nasal challenge is followed by oral challenge to rule out AERD beyond reasonable doubt ${ }^{(47)}$.

\section{Treatment options in AERD}

Treatment of AERD requires consideration of the upper and lower airways as one unit. Conventional therapies with nasal / inhaled steroids or oral steroids are frequently used. The European study of AERD patients found $80 \%$ of patients were being treated with inhaled steroids and $51 \%$ oral steroids ${ }^{(6)}$. LTR1A and 5-Lipoxygenase inhibitors (5-LOINH) are also useful in treatment and have proven efficacy in AERD ${ }^{\text {(48,49) }}$ (carriers of the $C$ allele of LTC4S and HLA-DPB $1{ }^{*} 0301$ marker may be 
Table 1. Approaches to diagnosis of aspirin / salicylate intolerance, the mechanism tested and its relative advantages and disadvantages.

\begin{tabular}{|c|c|c|c|}
\hline Test & Immune mechanism of test & Advantages & Disadvantages \\
\hline History alone & $\begin{array}{l}\text { None. Rely on knowledge of patho- } \\
\text { logical mechanism (and high / low } \\
\text { risk foods). }\end{array}$ & $\begin{array}{l}\text {-Simple } \\
\text {-Cheap }\end{array}$ & $\begin{array}{l}\text {-Relies on patient history / recall } \\
\text { alone and extent of questioning by } \\
\text { physician. } \\
\text {-Subjective with no objective } \\
\text { validation of findings } \\
\text {-Poor sensitivity } \\
\text {-Diagnostic uncertainly in foods } \\
\text { where other allergens / mecha- } \\
\text { nisms might be responsible for } \\
\text { symptoms and } \\
\text { high variation in salicylate contents } \\
\text { in different foods. }\end{array}$ \\
\hline $\begin{array}{l}\text { Double Blinded Placebo Control- } \\
\text { led Food Challenge (of offending } \\
\text { foods) }\end{array}$ & $\begin{array}{l}\text { Elicitation of symptoms directly by } \\
\text { blinded contact with food allergen. }\end{array}$ & $\begin{array}{l}\text {-Generally perceived as "gold } \\
\text { standard" test in food allergy. }\end{array}$ & $\begin{array}{l}\text {-Not generally applicable to AERD } \\
\text { as food salicylate levels vary con- } \\
\text { siderably and more 'pure' aspirin } \\
\text { elicitor available } \\
\text {-Time consuming \& expensive. }\end{array}$ \\
\hline Oral Challenge (with aspirin) & $\begin{array}{l}\text { Oral ingestion of aspirin leads to } \\
\text { bronco-constriction - } 20 \% \text { drop in } \\
\text { FEV }_{1}=\text { positive. }\end{array}$ & $\begin{array}{l}\text {-Considered gold standard in AERD } \\
\text { (43). }\end{array}$ & $\begin{array}{l}\text {-Only confirms rapid reactions such } \\
\text { as asthma and not slow reactions } \\
\text { such as nasal polyp growth. } \\
\text {-Severe reactions possible. }\end{array}$ \\
\hline Intra-nasal Challenge & $\begin{array}{l}\text { Inhalation of L-lysine-aspirin } \\
\text { leads to symptoms via pathways } \\
\text { described above. Observe for fall in } \\
\text { nasal flow. }\end{array}$ & $\begin{array}{l}\text {-Lower risk of severe reaction than } \\
\text { oral or inhaled challenge because } \\
\text { of poor absorption of Lys-ASA }(44)\end{array}$ & $\begin{array}{l}\text { - Lys-ASA not available in some } \\
\text { countries. } \\
\text {-Relatively more expensive to per- } \\
\text { form and time consuming. }\end{array}$ \\
\hline $\begin{array}{l}\text { Inhaled Challenge } \\
\text { (with L-lysine-aspirin) }\end{array}$ & $\begin{array}{l}\text { Inhalation of L-lysine-aspirin leads } \\
\text { to bronco-constriction Change in } \\
\text { FEV }_{1} \text { measured. }\end{array}$ & $\begin{array}{l}\text {-Similar sensitivity to oral chal- } \\
\text { lenge. }\end{array}$ & $\begin{array}{l}\text { - Lys-ASA not available in some } \\
\text { countries. } \\
\text {-Relatively more expensive to per- } \\
\text { form and time consuming. }\end{array}$ \\
\hline $\begin{array}{l}\text { Basophil Activation Test } \pm \text { Sulfido- } \\
\text { leukotriene Release Assay }{ }^{(45)}\end{array}$ & $\begin{array}{l}\text { Patient sera is added to a sample } \\
\text { of aspirin in a basophil stimulation } \\
\text { buffer. Degranulation occurs which } \\
\text { releases CD } 63 \text { which can be mea- } \\
\text { sured by a CD } 63 \text { marker. } \\
\text { The concentration of the released } \\
\text { sulfidoleukotrienes is measured by } \\
\text { ELISA using specific monoclonal } \\
\text { antibody }\end{array}$ & -Simple blood / laboratory test. & $\begin{array}{l}\text { - Generally poor sensitivity and not } \\
\text { considered reliable for diagnosis }{ }^{(45)} \text {. }\end{array}$ \\
\hline Urinary LTE4 excretion ${ }^{(10)}$ & $\begin{array}{l}\text { Often used in conjunction with } \\
\text { challenge testing. Baseline LTE4 le- } \\
\text { vels are } 3-5 \times \text { higher in AIA patients. }\end{array}$ & $\begin{array}{l}\text { Easy to perform via simple urine } \\
\text { specimen. }\end{array}$ & $\begin{array}{l}\text { High rate of false positives as some } \\
\text { aspirin tolerant patients also have } \\
\text { raised LTE4 }{ }^{(10)} \text {. }\end{array}$ \\
\hline $\begin{array}{l}\text { ASA induced 15-HETE secretion } \\
\text { ASPITest }^{\left({ }^{(46)} \text {. }\right.}\end{array}$ & $\begin{array}{l}\text { Aspirin can trigger release of } 15- \\
\text { HETE from peripheral blood leuko- } \\
\text { cytes in AERD patients in vitro. }\end{array}$ & $\begin{array}{l}\text {-Simple blood / laboratory test. } \\
\text {-Reasonably good sensitivity and } \\
\text { specificity. }\end{array}$ & $\begin{array}{l}\text {-Unvalidated for use in diagnosis } \\
\text { (46). }\end{array}$ \\
\hline
\end{tabular}

particularly sensitive to LTRAs). Con-current allergy to common aeroallergens should also be addressed as appropriate (allergen avoidance, anti-histamines, immunotherapy and anti-lgE). Sinus surgery will often be required in AERD patients. The ENT surgeon, respiratory physician, allergist and dietician may need to co-operate in given individual patients.

\section{Avoidance of NSAIDs}

Patients with AERD are often advised to avoid all COX1 inhibitors. However, a universal avoidance of all NSAIDs in all asthmatic patients would deprive $80 \%$ of the safe use of these effective medications. One option is to give the first dose under clinical supervision. COX2 specific inhibitors are generally safe in AERD, 
Table 2. Foods which are high, medium and low in salicylates - adapted from published data on the salicylate content of foods mg/kg ${ }^{(32-35)}$.

\begin{tabular}{|c|c|c|c|c|}
\hline & HIGH & MEDIUM & LOW & NEGLIGABLE or FREE \\
\hline & $>0.5 \mathrm{mg}$ per portion & 0.1-0.5mg per portion & 0.01-0.09 mg per portion & $<0.01 \mathrm{mg}$ per portion \\
\hline $\begin{array}{l}\text { FRUITS } \\
\text { Per portion e.g. one apple, } \\
\text { ten strawberries. }\end{array}$ & $\begin{array}{l}\text { Granny Smith apples, } \\
\text { cherries, strawberries. }\end{array}$ & $\begin{array}{l}\text { Currants, raisins, kiwi, } \\
\text { Gala melon, peaches and } \\
\text { nectarines. }\end{array}$ & $\begin{array}{l}\text { Golden Delicious apples, } \\
\text { banana, blackberries, blue- } \\
\text { berries, grapefruit, lemon, } \\
\text { mango, honeydew melon, } \\
\text { orange, pear (peeled), } \\
\text { plums. }\end{array}$ & Grapes, lime, raspberry. \\
\hline $\begin{array}{l}\text { VEGETABLES } \\
\text { Per portion of e.g. one to- } \\
\text { mato, five asparagus spears. }\end{array}$ & & $\begin{array}{l}\text { Asparagus, sweet corn, raw } \\
\text { tomatoes, tomato puree. }\end{array}$ & $\begin{array}{l}\text { Broccoli, carrot, mange tout, } \\
\text { peas, peppers. }\end{array}$ & $\begin{array}{l}\text { Aubergine, cabbage, cau- } \\
\text { liflower, celery, cucumber, } \\
\text { green beans, lettuce, } \\
\text { mushroom, potato, swede. }\end{array}$ \\
\hline $\begin{array}{l}\text { HERBS \& SPICES } \\
\text { per one teaspoon spices, } \\
\text { garlic clove, cube of ginger } \\
\text { etc. }\end{array}$ & $\begin{array}{l}\text { Ginger, mixed herbs, } \\
\text { mustard, oregano. }\end{array}$ & $\begin{array}{l}\text { Black pepper, cardamom } \\
\text { pods, cinnamon, cumin, } \\
\text { fenugreek, mint, nutmeg, } \\
\text { paprika, rosemary, thyme, } \\
\text { turmeric. }\end{array}$ & $\begin{array}{l}\text { Coriander, chilli, fennel, } \\
\text { garam masala, garlic, hor- } \\
\text { seradish. }\end{array}$ & \\
\hline $\begin{array}{l}\text { BEVERAGES } \\
\text { Per portion e.g. glass of fruit } \\
\text { juice, mug of tea, half pint } \\
\text { of cider. }\end{array}$ & $\begin{array}{l}\text { Coffee, pineapple juice, } \\
\text { cider, Benedictine liqueur. }\end{array}$ & $\begin{array}{l}\text { Lemon tea, black tea, } \\
\text { apple juice, cranberry } \\
\text { juice, orange juice, tomato } \\
\text { juice, fizzy drinks, Drambui } \\
\text { liqueur, wine, rum. }\end{array}$ & $\begin{array}{l}\text { Camomile tea, peppermint } \\
\text { tea, grapefruit juice, lager. }\end{array}$ & Gin, vodka. \\
\hline $\begin{array}{l}\text { OTHER } \\
\text { Per teaspoon, except for } \\
\text { tomato ketchup - per } 15 \mathrm{~g} \\
\text { sachet. }\end{array}$ & $\begin{array}{l}\text { Liquorice, Peppermint } \\
\text { (per } 100 \mathrm{~g} \text { ). }\end{array}$ & $\begin{array}{l}\text { Worcestershire sauce, } \\
\text { honey, tomato ketchup. }\end{array}$ & White wine vinegar. & $\begin{array}{l}\text { Malt vinegar, yeast extract, } \\
\text { golden syrup, rice, wheat, } \\
\text { oats, barley, corn, meat, } \\
\text { seafood, eggs, cheese, milk. }\end{array}$ \\
\hline
\end{tabular}

but where initiated for the first time, should be done with caution. COX1 avoidance will avoid acute symptoms.

\section{Low salicylate diets}

Due to the difficulties of implementing dietary avoidance of foods high in salicylic acid, and the discrepancies in salicylate content between studies, it is impossible to give any recommendations on dietary measures for patients with AERD. The presence of aspirin sensitivity, especially if this co-exists with nasal polyps or asthma, may indicate a role for dietary salicylate, but given the lack of hard evidence, a dietary salicylate restriction should only be implemented where these conditions are accompanied by a very clear history of reactions to foods high in natural salicylate. If a dietary exclusion is to be implemented as a treatment, it must have been preceded by a diagnostic diet for six weeks, followed by re-introduction of foods, to prove the efficacy of an exclusion of high salicylate foods (Table 2). Dietary salicylate has been shown to confer important health benefits, and a low salicylate diet is very restrictive, so it is vital to demonstrate the necessity of long-term exclusion, and ensure only those foods really high in natural salicylate are avoided.

\section{Oral Aspirin desensitisation \\ Who is it suitable for?}

Aspirin Desensitisation (AD) now has an established therapeutic role in patients with $A E R D{ }^{(50)}$. Eligible patients include those with moderate to severe asthma and / or intractable nasal blockage who have failed to respond to topical corticosteroids, LTRAs and to 5-LOINHs. Additionally suitable, are AERD patients with nasal polyps requiring multiple operations and patients requiring long term systemic corticosteroids to control disease. $A D$ may also benefit patients with $A E R D$ who require aspirin or other COX-1 inhibitors for secondary prevention of cardiovascular disease, thromboembolic disease or rheumatic diseases ${ }^{(51)}$.

\section{Patient outcomes after AD / evidence base}

Table 3 summarises relevant studies investigating oral AD. Early case reports in the 1970's demonstrated refraction to the adverse effects of aspirin while taking daily aspirin and even for a few days after discontinuation. Dramatic improvements in nasal and asthma symptoms were noted after $A D{ }^{(52)}$.

This led Stevenson et al. to conduct the first randomised, double blind, placebo-controlled (RDBPC) cross-over study of the effectiveness of $A D{ }^{(54)}$. After 3 months, patients enjoyed 


\begin{tabular}{|c|c|c|c|}
\hline Study & Trial design & Outcomes measures & Outcomes \\
\hline $\begin{array}{l}\text { Stevenson et al., } 1984 \text { (54) } \\
\text { "Scripps Clinic" }\end{array}$ & $\begin{array}{l}-25 \text { AERD patients } \\
\text {-RDBPC cross over trial over } 3 \\
\text { months (dose } 325-1300 \mathrm{mg} / \mathrm{d} \text { ). }\end{array}$ & $\begin{array}{l}\text {-Nasal symptoms scores } \\
\text {-Asthma symptoms } \\
\text {-FEV1 } \\
\text {-Asthma medication usage }\end{array}$ & $\begin{array}{l}\text {-Significant improvements on nasal } \\
\text { symptoms and need for nasal ste- } \\
\text { roids, half improved their asthma } \\
\text { symptoms. }\end{array}$ \\
\hline $\begin{array}{l}\text { Sweet et al., } 1990^{(55)} \\
\text { "Scripps Clinic" }\end{array}$ & $\begin{array}{l}\text {-107 AERD patients } \\
\text {-Retrospective review of } 65 \text { treated } \\
\text { with desensitisation (mean dose } \\
1300 \mathrm{mg} / \mathrm{d} \text { ) compared with } 42 \text { on } \\
\text { NSAID avoidance. } \\
\text {-Follow up for at least } 12 \text { months, } \\
\text { mean follow up } 51 \text { months. }\end{array}$ & $\begin{array}{l}\text {-Number of sinus infections \& } \\
\text { operations. } \\
\text {-Nasal symptom scores } \\
\text { \& asthma scores. } \\
\text {-Systemic and inhaled steroid use. } \\
\text {-Emergency Department (ED) and } \\
\text { unscheduled outpatient visits. }\end{array}$ & $\begin{array}{l}\text {-Reduced number of hospitalisati- } \\
\text { ons, ED and outpatient visits, upper } \\
\text { airway infections and surgery and } \\
\text { better olfaction. Reduced systemic } \\
\text { corticosteroid use and inhaled (in } \\
\text { continuous therapy group only). } \\
-46 \% \text { on treatment discontinued } \\
\text { because of side effects. }\end{array}$ \\
\hline $\begin{array}{l}\text { Stevenson et al., } 1996^{(56)} \\
\text { "Scripps Clinic" }\end{array}$ & $\begin{array}{l}75 \text { AERD patients } \\
\text {-Prospective cohort } \\
\text { mean dose } 1214 \mathrm{mg} / \mathrm{d} \text {. } \\
\text {-Mean } 3.1 \text { year follow up. }\end{array}$ & $\begin{array}{l}\text {-Number of sinus infections and } \\
\text { sinus operations. } \\
\text {-Olfaction scores. } \\
\text {-Hospital admissions \& ED visits for } \\
\text { asthma. } \\
\text {-Systemic and topical steroid doses. }\end{array}$ & $\begin{array}{l}\text {-Significant reduction in need for } \\
\text { sinus surgery, infections, asthma } \\
\text { hospitalisations, olfaction scores } \\
\text { and need for steroids. }\end{array}$ \\
\hline McMains et al., $2006^{(57)}$ & $\begin{array}{l}-15 \text { AERD patients. } \\
\text {-Retrospective analysis of patients } \\
\text { undergoing FESS } \\
-5 \text { underwent desensitisation, } 10 \\
\text { did not. } \\
-24 \text { month follow up. }\end{array}$ & $\begin{array}{l}\text {-SNOT } 20 \text { scores } \\
\text {-Surgery rate } \\
\text {-Endoscopy scores (Rhinosinusitis } \\
\text { task force methodology) }\end{array}$ & $\begin{array}{l}\text {-None of } 5 \text { patients on aspirin } \\
\text { therapy required additional surgery } \\
\text { compared with } 8 / 10 \text { who required } \\
\text { surgery when not on therapy } \\
p=0.003 \text {. }\end{array}$ \\
\hline $\begin{array}{l}\text { Berges-Gimeno et al., } 2003^{(58)} \\
\text { "Scripps Clinic" }\end{array}$ & $\begin{array}{l}-172 \text { AERD patients. } \\
\text {-Prospective analysis. } \\
-126 \text { continued therapy for at least } \\
1 \text { year. } \\
\text {-Mean dose } 1138 \mathrm{mg} / \mathrm{d} \text {. }\end{array}$ & $\begin{array}{l}\text {-Number of sinus infections and } \\
\text { sinus operations. } \\
\text {-Rhinitis and asthma symptom } \\
\text { scores. } \\
\text {-Olfaction scores. } \\
\text {-Hospital admissions \& ED visits for } \\
\text { asthma. } \\
\text {-Systemic and topical steroid doses. }\end{array}$ & $\begin{array}{l}-87 \% \text { improvement in those who } \\
\text { completed } 1 \text { year of treatment. } \\
\text {-Prednisolone dose reduction from } \\
10.8 \mathrm{mg} / \mathrm{d} \text { to } 8.1 \mathrm{mg} / \mathrm{d} \text { at } 6 \text { months } \\
\text { and } 3.6 \mathrm{mg} / \mathrm{d} \text { at } 1 \text { year. } \\
-14 \% \text { discontinued because of side } \\
\text { effects. } \\
\text {-Treatment still effective at } 5 \mathrm{yrs} \\
\text { follow up. }\end{array}$ \\
\hline $\begin{array}{l}\text { Lee et al 2007., (59) } \\
\text { "Scripps Clinic" }\end{array}$ & $\begin{array}{l}\text {-137 AERD patients. } \\
\text {-Randomised Controlled trial com- } \\
\text { paring } 325 \mathrm{mg} \text { bd or } 650 \mathrm{mg} \text { bd. }\end{array}$ & $\begin{array}{l}\text {-No of sinus infections and sinus } \\
\text { operations. } \\
\text {-Rhinitis and asthma symptom } \\
\text { scores. } \\
\text {-Olfaction scores. } \\
\text {-Hospital admissions for asthma. } \\
\text {-Systemic and topical steroid doses. }\end{array}$ & $\begin{array}{l}\text {-Improvement in sinus infections, } \\
\text { operations, } p<0.0001 \text {. } \\
\text {-Anosmia, nasal and asthma symp- } \\
\text { tom improvement } p<0.03 \text {. } \\
-3-4 \text { fold decrease in steroid doses. } \\
\text {-No difference between treatment } \\
\text { doses. }\end{array}$ \\
\hline Rozsasi et al., $2008^{(60)}$ & $\begin{array}{l}\text {-14 AERD patients. } \\
\text {-Randomly assigned to } 100 \mathrm{mg} \text { or } \\
300 \mathrm{mg} \text { of aspirin daily. } \\
\text {-Second phase of study observed } \\
\text { subsequent patients treated with } \\
300 \mathrm{mg} \text { daily ( } 39 \text { patients in total). }\end{array}$ & $\begin{array}{l}\text {-Endoscopic polyp appearances. } \\
\text {-Rhinomanometry. } \\
\text {-Olfaction tests. } \\
\text {-Validated QOL asthma and sinusi- } \\
\text { tis scores. } \\
\text {-FEV1. } \\
\text {-Medication scores. } \\
\text {-Number of sinus operations. }\end{array}$ & $\begin{array}{l}\text {-300mg group showed significant } \\
\text { improvement in polyp recurrence, } \\
\text { sinus symptom scores \& nasal } \\
\text { patency. } \\
\text {-Asthma symptom scores improved } \\
\text { after longer term treatment. } \\
\text {-100mg dose inadequate. }\end{array}$ \\
\hline Forer et al 2011., ${ }^{(61)}$ & $\begin{array}{l}\text { - } 27 \text { enrolled patients (only } 12 \text { after } \\
\text { discontinuations) } \\
\text { - Prospective analysis with } \\
625 \mathrm{mg} \text { bd }\end{array}$ & $\begin{array}{l}\text { - Endoscopic polyp appearances } \\
\text { - Visual analogue symptom scales }\end{array}$ & $\begin{array}{l}\text { - Non significant reduction in polyp } \\
\text { size } \\
\text { - Significant reduction in symptoms } \\
\text { of nasal congestion, discharge and } \\
\text { discomfort }\end{array}$ \\
\hline
\end{tabular}


Table 4. Summary of adverse events in larger studies ( $>65$ patients) of oral AD.

\begin{tabular}{|c|c|c|c|}
\hline Study & Aspirin related side effects & $\begin{array}{l}\text { Other side effects / discontinu- } \\
\text { ations }\end{array}$ & Total discontinuations \\
\hline $\begin{array}{l}\text { Sweet et al. } 1990^{(55)} \\
\text { "Scripps Clinic" }\end{array}$ & $12 / 65-18 \%$ & $\begin{array}{c}18 / 65-28 \% \\
\text { ("unclear" reasons for many of } \\
\text { these discontinuations) }\end{array}$ & $30 / 64-46 \%$ \\
\hline $\begin{array}{l}\text { Stevenson et al. } 1996^{(56)} \\
\text { "Scripps Clinic" }\end{array}$ & $9 / 75-12 \%$ & $1 / 75-1 \%$ & $10 / 75-13 \%$ \\
\hline $\begin{array}{l}\text { Berges-Gimeno et al. } 2003^{\left({ }^{(5)}\right)} \\
\text { "Scripps Clinic" }\end{array}$ & $24 / 172-14 \%$ & $22 / 72-13 \%$ & $46 / 172-27 \%$ \\
\hline $\begin{array}{l}\text { Lee et al. } 2007^{(59)} \\
\text { "Scripps Clinic" }\end{array}$ & $\begin{array}{l}19 / 137-14 \% \\
\text { (plus } 7 \text { when including effects } \\
\text { before down-dosing) }-20 \%\end{array}$ & $3 / 137-2 \%$ & $22 / 137-16 \%$ \\
\hline
\end{tabular}

Table 5. Summary of reports and trials of Intranasal Lysine-Acetlysalicylate desensitisation.

\begin{tabular}{|c|c|c|c|}
\hline Study & Trial design & Outcomes measures & Outcomes \\
\hline Patriarca et al. $1991^{(66)}$ & $\begin{array}{l}-43 \text { patients desensitised with in- } \\
\text { creasing LAS doses up to } 2000 \mathrm{mcg} \\
\text { weekly. } \\
-28 \text { had AERD and } 15 \text { were aspirin } \\
\text { tolerant. } \\
-5 \text { year follow up. } \\
\text {-compared with } 191 \text { other post } \\
\text { op polyp patients ( } 130 \text { of which } \\
\text { AERD). }\end{array}$ & -Rate of polyp recurrence. & $\begin{array}{l}\text {-Polyp recurrence significantly } \\
\text { reduced } 32 \% \text { vs } 81 \%, p<0.0001 \text {. }\end{array}$ \\
\hline Scadding et al. $1995^{(67)}$ & $\begin{array}{l}\text {-20 aspirin tolerant patients treated } \\
\text { with LAS weekly in one nostril and } \\
\text { saline in the other for } 15 \text { months. } \\
\text {-Compared with rates expected } \\
\text { from previous experience. }\end{array}$ & $\begin{array}{l}\text {-Polyp recurrence on nasendo- } \\
\text { scopy. } \\
\text {-Acoustic rhinometry. }\end{array}$ & $\begin{array}{l}\text { Significant delay in polyp recur- } \\
\text { rence compared with expected } \\
\text { from previous experience. }\end{array}$ \\
\hline Nucera et al. $2000^{(68)}$ & $\begin{array}{l}\text {-Prospective comparative study. } \\
-76 \text { patients treated with LAS six } \\
\text { times per week. } \\
-49 \text { patients had 'medical polypec- } \\
\text { tomy' followed by LAS. } \\
\text {-'Control group' of } 191 \text { patients } \\
\text { having surgery. } \\
\text {-Included aspirin sensitive and } \\
\text { tolerant patients }\end{array}$ & $\begin{array}{l}\text {-Recurrence of polyps based on } \\
\text { ENT examination and CT scan. }\end{array}$ & $\begin{array}{l}\text {-Significant reduction in polyp } \\
\text { recurrence in LAS group after } \\
\text { surgery. } \\
\text {-Half of patients were "aspirin sensi- } \\
\text { tive" and one third had positive LAS } \\
\text { challenge testing. }\end{array}$ \\
\hline Parikh et al. $2005^{(69)}$ & $\begin{array}{l}\text {-Randomised double blind placebo } \\
\text { controlled cross over trial in } 11 \\
\text { patients with AERD and polyps. }\end{array}$ & $\begin{array}{l}\text {-Acoustic rhinometry } \\
\text {-NIPF } \\
\text {-PEFR } \\
\text {-Nasal and chest symptom scores } \\
\text { (VAS) }\end{array}$ & $\begin{array}{l}\text {-Poor clinical effect but significant } \\
\text { improvement at microscopic level. }\end{array}$ \\
\hline Ogata et al. $2007^{(70)}$ & $\begin{array}{l}\text { Open uncontrolled study of } 13 \\
\text { AERD patients }\end{array}$ & $\begin{array}{l}\text {-Nasal symptoms scores } \\
\text {-NO levels } \\
\text {-NIPF } \\
\text {-PEFR } \\
\text {-Nasendoscopic grading of polyps }\end{array}$ & $\begin{array}{l}\text {-Reduction in polyp size on } \\
\text { nasendoscopy but no reduction in } \\
\text { symptoms or PEFR. }\end{array}$ \\
\hline
\end{tabular}


significant improvement in nasal symptoms and reduction in nasal corticosteroid use compared with placebo. There was no significant improvement in asthma symptoms or reduction in systemic steroid dose. Some of the limited success in the asthma outcomes may be attributed to underdosing of aspirin in one third of participants. Additionally, patients with sinus disease did not all receive maximal medical therapy prior to desensitisation, which may have influenced outcomes.

The same group at the Scripps clinic, published four further studies from 1990 - $2007^{(55,56,58,59)}$. Their 1990 publication retrospectively compared 65 AERD patients treated with AD with 42 who avoided NSAIDs. Statistically significant reductions in nasal and asthma symptoms / treatments occurred in the AD group.

Limitations of this study include the milder disease status of the 'control' group and that $46 \%$ discontinued aspirin treatment.

Also, the retrospective and non-randomised nature of the study introduces potential recall and selection bias.

The 1996 series prospectively studied pre and post treatment status in 75 patients ${ }^{(56)}$. Co-morbid sinus disease had already been optimised. Highly significant reductions were seen in sinus infections per year, asthma hospitalisations, olfaction symptom scores and doses of systemic and nasal corticosteroids. Sinus surgery rates were reduced from once every three years to once every ten years. This reduction in frequency of surgery was also noted in a small retrospective comparative study by McMains et al. ${ }^{(57)}$. The 2003 observational cohort re-affirmed previous findings ${ }^{(58)}$. Significant improvements were achieved within 6 months of therapy and this was maintained during the 5 years of follow-up. Benefit of steroid reduction was seen as early as one month after initiation of therapy ${ }^{(62)}$.

The most recent report from Scripps compared two doses of aspirin therapy ( $1250 \mathrm{mg}$ and $650 \mathrm{mg}$ daily) in a randomised trial ${ }^{(59)}$. Patients were allowed to switch between groups to minimise side effects or maximise therapeutic benefit. After one year of treatment, there were significant reductions in all upper and lower airway parameters with no difference between group efficacy and side effects. In the light of this, a group in Germany compared even lower doses ${ }^{(60)}$. After one year of treatment, all of the $100 \mathrm{mg}$ group developed recurrent polyps whereas none of the $300 \mathrm{mg}$ group did. Nasal patency improved in the $300 \mathrm{mg}$ group and deteriorated in the $100 \mathrm{mg}$ group. Sinusitis scores improved only in the $300 \mathrm{mg}$ group but failed to reach statistical significance. No improvement in asthma scores were seen in either group, although the $300 \mathrm{mg}$ group did have significantly improved FEV 1 . Eventually, 39 patients received at least one year of $300 \mathrm{mg}$ therapy achieving significant improvements in asthma and sinus symptoms scores.

These studies consistently show that $A D$ and daily aspirin therapy, at sufficient dosing, results in significant reductions in asthma and nasal symptoms, treatment requirements and unscheduled physician visits. However, several problems exist with this evidence base. One major limitation is the lack of RDBPC trials which would provide higher level evidence. Most of the trials are retrospective with potential selection, observer and recall bias. Donaldson describes the problems he encountered conducting RDBPC trials in AD ${ }^{(56)}$. After his initial trial ${ }^{(54)}$, he attempted to conduct a long term RDBPC trial, but after two years recruited only two patients. Both these patients were allocated placebo and both dropped out within weeks due to return of symptoms. Patients on aspirin notice an immediate improvement in symptoms making blinding difficult. Also, aspirin is freely available over the counter, making full control of use by investigators impossible. Additionally, patients are required to have full disclosure of therapy options when entering such a trial, including open treatment with aspirin. This may have hampered recruitment to such trials. Another problem with the evidence base is that the overwhelming majority of the dataset derives from one institution. This introduces potential for biased interpretation of outcomes and relative lack of correlation with other groups.

\section{Adverse events and safety of oral $A D$}

Another practical issue is the patient drop-out rate of $10-20 \%$ due to adverse effects, in particular dyspepsia. Table 4 summarises adverse events / discontinuations in the larger studies. Interestingly, Lee et al. noticed no difference in dyspepsia in higher and lower dose aspirin groups ${ }^{(59)}$. None of the studies enquired about anti-acid medication use and the effect this may have on side effects. No trial reported any death.

During initial challenge protocols, reactions are common with naso-ocular symptoms in $90 \%$ and bronchial symptoms in 35\% ${ }^{(63)}$. The severity of historical reactions does not seem to predict severity of reaction during challenge ${ }^{(63)}$. Donaldson comments that in the Scripps clinic experience of 1375 challenges, none required intubation / ventilation ${ }^{(64)}$. With careful optimisation prior to desensitisation, adverse events are minimised, and at Scripps, 102 patients were successfully desensitised in the outpatient setting from 2005-2008 ${ }^{(65)}$.

\section{Conclusions of oral AD treatment}

In summary, there is consistent moderate level evidence to support the efficacy of AD in AERD. However, the evidence base does have methodological limitations and potential biases. Side effects of aspirin therapy are fairly frequent. With careful selection and medical optimisation, $A D$ is a safe and effective adjunctive treatment in AERD. Further well designed trails of $A D$ would greatly benefit the evidence base. 
Intranasal Lysine-Acetylsalicylate (LAS) desensitisation Intranasal administration of LAS has been investigated in the treatment of nasal polyposis in AERD. Table 5 summarises these studies. Patriarca et al. ${ }^{(66)}$ treated post operative nasal polyp patients with increasing doses of LAS. Outcomes were compared to a control group of 191 patients with polyps (130 of whom had aspirin intolerance) undergoing surgery. Patients receiving LAS had lower polyp recurrence rates than controls ( $32 \%$ vs $81 \%$, $\mathrm{p}<0.0001)$.

The same group later performed a prospective comparative study of patients treated with LAS after surgical polypectomy and a group receiving medical therapy with intramuscular steroids, followed by LAS therapy ${ }^{(68)}$. When compared to a 'control' group of patients receiving surgery alone, post-LAS polyp recurrence was significantly reduced. This study has several methodological flaws. The study is non-randomised and un-blinded. It is unclear if the control group had LAS provocation testing and no detail is provided for what proportion were aspirin sensitive. It would seem also that the control group was the same used in their study nine years earlier, suggesting historical controls. This introduces further potential biases. Interestingly, no difference was observed in outcomes between aspirin sensitive and tolerant patients. This implies that LAS therapy benefits all polyp patients, as suggested by Scadding et al. who demonstrated delay in polyp recurrence and size (compared to expected rate based on previous experience) after weekly LAS treatment for 15 months ${ }^{(67)}$.

Parikh et al. performed the first randomised DBPC cross over trial of LAS therapy in confirmed AERD patients ${ }^{(69)}$. LAS was no better than placebo in their outcome measures. Their power calculation required 12 patients, and unfortunately after dropouts, they recruited only 11 patients. The treatment groups had not had recent surgery. Nucera suggested that LAS works better after surgery ${ }^{(68)}$. This might partly account for the lack of efficacy. Ogata et al. also performed an uncontrolled open study demonstrating significant reduction in polyp size but not in symptoms or PEFR ${ }^{(70)}$.

\section{Conclusions of intra-nasal AD treatment}

In summary, studies of LAS desensitisation are few and generally of poor quality. There is a possible trend to reduction in nasal polyp size and recurrence. There is no improvement in nasal symptoms or asthma control. Further better designed trails may clarify the uncertainty raised by these studies. Although intranasal LAS may be associated with less adverse events, oral AD is cheaper, easier, and has better outcomes. Thus any impetus to perform further LAS trials, may be impeded by this superior alternative.
Taking aspirin desensitisation into practice

The role of aspirin desensitisation in the management of AERD was considered in the 2005 practice parameter update of the AAAAI and ACAAI ${ }^{(71)}$. This group recommended that AD should be considered in all patients with AERD. Surprisingly, AD did not form part of any summary recommendations of the 2007 EPOS3 guidelines ${ }^{(72)}$. However, much more information is provided on the diagnosis and potential role of $A D$ in the 2012 update ${ }^{(73)}$.

Poor awareness of the AERD syndrome and lack of AD services is problematic ${ }^{(74)}$. Awareness may now be increasing in the UK; evidenced by the Cochrane review currently underway investigating $A D^{(75)}$ and the addition of the favourable US economic analysis of $A D{ }^{(2)}$ to the NHS Economic Evaluation Database ${ }^{(76)}$. This analysis affirms the cost effectiveness of AD in AERD and to a lesser extent in secondary cardiovascular prophylaxis. Locally based economic analyses would further help clinicians seeking funds to set up local services.

Several challenges remain to achieve wider establishment of AD. Patients and physicians need to be more aware of the AERD syndrome and the benefits of desensitisation ${ }^{(74)}$. Practical issues administering $A D$ may also be inhibiting its wider establishment. $A D$ is labour intensive and time consuming. It usually requires a dedicated nurse for administering drugs and monitoring the patient. Space is required, and using this space may mean loss of other more financially viable services ${ }^{(51)}$. Recent studies have, however, identified factors which may facilitate time saving during $A D^{(77,78)}$.

\section{Conclusion}

AERD is associated with significant patient morbidity and healthcare costs. The disease tends to follow a typical course. There are established standards for challenge testing in AERD. Management of nasal disease is important to achieve better control of asthma. The role for the exclusion of dietary salicylic acid in the treatment of AERD has yet to be established. Any dietary interventions should involve an experienced dietitian, to advise on how best to avoid such foods whilst maintaining a healthy diet. Reasonable quality evidence exists for the role of oral $A D$ in the management of patients with moderate to severe disease. However poor awareness of AERD and AD probably accounts for the under-utilisation of this treatment. Further better quality studies from alternative institutions coupled with measures to improve knowledge of the disease and treatments will improve patient care and decrease healthcare costs.

\section{Authorship contribution}

JM: Researched and wrote all aspects of this paper (apart from those relating to dietary salicylate and low salicylate diets).

IS: Researched and wrote all aspects relating to dietary salicylate 


\section{References}

1. Szczeklik A, Stevenson DD: Aspirin-induced asthma: advances in pathogenesis and management. J Allergy Clin Immunol. 1999; 104: 5-13.

2. Shaker M, Lobb A, Jenkins P, O'Rourke D, Takemoto SK, Sheth S et al. An economic analysis of aspirin desensitization in aspirinexacerbated respiratory disease. J Allergy Clin Immunol. 2008; 121: 81-87.

3. Jenkins C, Costello J, Hodge L: Systematic review of prevalence of aspirin induced asthma and its implications for clinical practice. BMJ. 2004: 328: 434

4. Settipane GA. Aspirin sensitivity and allergy. Biomed Pharmacother. 1988; 42: 493-498.

5. Dursun AB, Woessner KA, Simon RA, Karasoy D, Stevenson DD. Predicting outcomes of oral aspirin challenges in patients with asthma, nasal polyps and chronic sinusitis. Ann Allergy Asthma Immunol. 2008; 100: 420-425.

6. Szczeklik A, Nizankowska E, Duplaga M. Natural History of aspirin-induced asthma. Eur Respir J. 2000; 16: 432-436.

7. Berges-Gimeno M, Simon RA, Stevenson DD. The natural history and clinical characteristics of aspirin exacerbated respiratory disease. Ann Allergy Asthma Immunol. 2002; 89: 474-478.

8. Yamashita T, Tsuyi H, Maeda N, Tomoda K, Kumazawa T. Etiology of nasal polyps associated with aspirin-sensitive asthma. Rhinology. 1989; 8: 15-24

9. Nasser SM, Pfister R, Christie PE, et al Inflammatory cell populations in bronchial biopsies from aspirin-sensitive asthmatic subjects. Am J Resp Crit Care Med. 1996; 153: 90-96.

10. Daffern PJ, Muilenburg D, Hugli TE, Stevenson DD. Association of urinary leukotriene E4 excretion during aspirin challenges with severity of respiratory responses. J Allergy Clin Immunol. 1999; 104: 559564.

11. Hamad AM, Sutcliffe AM, Knox AJ. Aspirininduced asthma:clinical aspects, pathogenesis and management. Drugs. 2004; 64: 2417-2432.

12. Sanak M, Pierzchalska M, Bazan-Socha S, Szczeklik A. Enhanced expression of the leukotriene C(4) synthase due to overactive transcription of an alleic variant associated with aspirin-intolerant asthma. Am J Respir Mol Biol. 2000; 23: 290-296.

13. Sousa A, Parikh A, Scadding G, Corrigan CJ Lee TH. Leukotriene-receptor expression on nasal mucosal inflammatory cells in aspirinsensitive rhinosinusitis. N Engl J Med. 2002; 347: 1524-1526.

14. Bochenek G, Nagraba K, Nizankowska
E, Szczeklik A. A controlled study of 9alpha,11beta-PGF2 (a prostaglandin D2 metabolite) in plasma and urine of patients with bronchial asthma and healthy controls after aspirin challenge. J Allergy Clin Immunol. 2003; 111: 743-749.

15. Pierzchalska M, Szabo Z, Sanak M, Soja J, Szczeklik A. Deficient prostaglandin E2 production by bronchial fibroblasts of asthmatic patients with special reference to aspirininduced asthma. J Allergy Clin Immunol. 2003; 111: 1041-1048.

16. Jinnai N, Sakagami T, Sekigawa $T$, Kakihara M, Nakajima T, Yoshida K, et al. Polymorphisms in the prostaglandin E2 receptor subtype 2 gene confer susceptibility to aspirin-intolerant asthma: a candidate gene approach. Hum Mol Genet. 2004; 13: 3203-3217.

17. Szczeklik A. Aspirin-induced asthma as a viral disease. Clin Alllergy. 1988; 18: 15-20.

18. Jeffreys D. Aspirin: The story of a wonder drug. 2004 London: Bloomsbury Publishing.

19. Baxter G, Paterson J, Wiles D, Graham A Shirastava R. Salicylic acid: the spice of life? Proc Nutr Soc. 2005; 64: 64A.

20. Paterson J, Baxter G, Lawrence J, Duthie G. Is there a role for dietary salicylates in health? Proc Nutr Soc. 2006; 65: 93-96.

21. Moore-Robinson M, Warin RP. Effect of salic ylates in urticaria. Br Med J. 1967; 4: 262-264.

22. Douglas HM. Dietary treatment of patients with chronic urticaria and intolerance to aspirin and food additives. Dermatologica. 1977; 154: 308-310

23. Juhlin L. Recurrant urticaria: Clinical investigation of 330 patients. Br J Dermatol. 1981; 104: 369-381

24. McDonald JR, Mathieson DA, Stevenson DD. Aspirin intolerance in asthma. detection by oral challenge. J Allergy. 1972; 50: 198-207.

25. Hare LG, Woodside JV, Young IS. Dietary salicylates. J Clin Pathol. 2003; 56: 649-650.

26. Amann R, Peskar BA. Anti-inflammatory effects of aspirin and sodium salicylate. Eur J Pharmacol. 2002; 447: 1-9.

27. Corder EH, Buckley CE. Aspirin, salicylate, sulfite and tartrazine-induced bronchoconstriction. Safe doses and case definition in epidemiological studies. J Clin Epidemiol. 1995; 48: 1269-1275.

28. Dahlén B, Boréus LO, Anderson P, Andersson R, Zetterström O. Plasma acetylsalicylic acid and salicylic acid levels during aspirin provocation in aspirin-sensitive subjects. Allergy. 1994; 49: 43-49.

29. Baenkler H-W. Salicylate Intolerance. Dtsch Arztebl Int. 2008; 105: 137-142.

30. Samter M, Beers RF. Concerning the nature of intolerance to aspirin, J Allergy. 1967; 40: 281-293.
31. Picado C, Fernandez-Morata JC, Juan M, Roca-Ferrer J, Fuentes M, Xaubet A, Mullol J. Cyclooxygenase-2 mRNA is downexpressed in nasal polyps from aspirin-sensitive asthmatics. Am Resp Crit Care Med. 1999; 160: 291-296.

32. Swain AR, Dutton SP, Truswell AS. Salicylates in Foods. J Am Diet Assoc. 1985; 85: 950960.

33. Venema DP, Hollman PCH, Janssen KPLTM Katan MB. Determination of acetylsalicylic acid and salicylic acid in foods, using HPLC with fluorescence detection. J Agric Food Chem. 1996; 44: 1762-1767.

34. Scotter MJ, Roberts DPT, Wilson LA, Howard FAC, Davis J, Mansell N. Free salicylic acid and acetyl salicylic acid content of foods using gas chromatography-mass spectrometry. Food Chem. 2007; 105: 273-279.

35. Wood A, Baxter G, Paterson J, Thies F, Duthie $\mathrm{G}$. Comparison of methods to determine salicylic acid content of fruit juices. Proc Nutr Soc. 2005; 64: 87A.

36. Janssen KTLPM, Hollman PCH, Venema DP, van Staveren WA, Katan MB. Salicylates in Foods. Nut Reviews. 1996; 54: 357-359.

37. Baxter G J, Graham AB, Lawrence JR, Wiles D, Paterson JR. Salicylic acid in soups prepared from organically and non-organically grown vegetables. Eur J Nutr. 2001; 40: 289-292.

38. Heiska S, Rousi M, Turtola S, Meier B, Tirkkonen $V$, Julkunen-Titto $R$. The effect of genotype and cultivation method on the total salicylate yield of dark leaved willows. Plant Medica. 2005; 71: 1134-1139.

39. Paterson JR, Srivastava R, Baxter GJ, Graham AB, Lawrence JR. Salicylic acid content of spices and its implications. J Agric Food Chem. 2006; 54: 2891-2896.

40. Amman R, Peskar BA. Anti-inflammatory effects of aspirin and sodium salicylate. Eur J Pharmacol. 2002; 447: 1-9.

41. Janssen KTLPM, Hollman PCH, Reichmann E, Venema DP, van Staveren WA, Katan MB. Urinary salicylate excretion in subjects eating a variety of diets shows the amounts of bioavailable salicylates in foods are low. Am J Clin Nutr. 1996; 64: 743-747.

42. Lawrence JR, Peter R, Baxter G, Robson J, Graham AB, Paterson JR. Urinary excretion of salicyluric and salicylic acids by non-vegetarians, vegetarians and patients taking low-dose aspirin. J Clin Pathol. 2003; 56: 651-653.

43. Nizankowska E, Bestynska-Krypel A, Cmiel A, Szczeklik A. Oral and bronchial provocation tests with aspirin for diagnosis of aspirin-induced asthma. Eur Respir J. 2000; 15: 863-869.

44. Alonso-Llamazares A, Martinez-Cocera C, 
Dominguez-Ortega J, Robledo-Echarren T, Cimarra-Alvarez M, Mesa del CM. Nasal provocation test (NPT) with aspirin: a sensitive and safe method to diagnose aspirininduced asthma (AIA). Allergy. 2002; 57: 632-635.

45. Gamboa P, Sanz ML, Caballero MR, Urrutia I, Antépara I, Esparza R, et al. The flow-cytometric determination of basophil activation induced by aspirin and other non-steroidal anti-inflammatory drugs (NSAIDs) is useful for in vitro diagnosis of the NSAID hypersensitivity syndrome. Clin Exp Allergy. 2004; 34: 1448-1457.

46. Kowalski ML, Ptasinska A, Jedrzejczak M, Bienkiewicz B, Cieslak M, Grzegorczyk J, et al. Aspirin triggered 15 HETE generation in peripheral blood leukocytes is a specific and sensitive Aspirin-Sensitive Patients Identification Test (ASPITest). Allergy. 2005; 60: 1139-1145.

47. Nizankowska-Mogilnicka E, Bochenek G, Mastalerz L, Swierczynska M, Picado C, Scadding G, et al. EAACI/GA2LEN guideline: aspirin provocation tests for diagnosis of aspirin hypersensitivity. Allergy. 2007; 62: 1111-1118.

48. Dahlen S, Malstrom K, Nizankowska E, et al. Improvement of aspirin-intolerant asthma by montelukast, a leukotriene antagonist. A randomised, double-blind, placebo-controlled trial. Am J Resp Crit Care Med. 2002; 165: 9-14.

49. Dahlen S, Nizankowska E, Szczeklik A, et al. The benefits of adding the 5-lipoxygenase inhibitor zileuton to conventional therapy in aspirin-intolerant asthmatics. Am J Resp Crit Care Med. 1998; 157: 1187-1194.

50. Macy E, Bernstein JA, Castells MC, Gawchik SM, Lee TH, Settipane RA, et al. Aspirin challenge and desensitization for aspirinexacerbated respiratory disease: a practice paper. Ann Allergy Asthma Immunol. 2007; 98: 172-174.

51. Stevenson DD, Simon RA. Selection of patients for aspirin desensitization treatment. J Allergy Clin Immunol. 2006; 118: 801-804.

52. Zeiss CR, Lockey RF. Refractory period to aspirin in a patient with aspirin-induced asthma. J Allergy Clin Immunol. 1976; 7: 440-448.

53. Stevenson DD, Simon RA, Mathison DA. Aspirin-sensitive asthma: tolerance to aspirin after positive oral aspirin challenges. J Allergy Clin Immunol. 1980; 66: 82-88.

54. Stevenson DD, Pleskow WW, Simon RA, Mathison DA, Lumry WR, Schatz M, et al. Aspirin-sensitive rhinosinusitis asthma: a double-blind crossover study of treatment with aspirin. J Allergy Clin Immunol. 1984; 73: 500-507.

55. Sweet JM, Stevenson DD, Simon RA, Mathison DA. Long-term effects of aspirin desensitization-treatment for aspirin-sensitive rhinosinusitis-asthma. J Allergy Clin Immunol. 1990; 85: 59-65.
56. Stevenson DD, Hankammer MA, Mathison DA, Christiansen SC, Simon RA. Aspirin desensitization of aspirin-sensitive patients with rhinosinusitis-asthma: long-term outcomes. J Allergy Clin Immunol. 1996; 98: 751-758.

57. McMains KC, Kountakis SE. Medical and surgical considerations in patients with Samter's triad. Am J Rhinol. 2006; 20: 573576.

58. Berges-Gimeno MP, Simon RA, Stevenson DD: Long-term treatment with aspirin desensitization in asthmatic patients with aspirin-exacerbated respiratory disease. Allergy Clin Immunol. 2003; 111: 180-186.

59. Lee JY, Simon RA, Stevenson DD. Selection of aspirin dosages for aspirin desensitization treatment in patients with aspirin-exacerbated respiratory disease. J Allergy Clin Immunol. 2007; 119: 157-164.

60. Rozsasi A, Polzehl D, Deutschle T, Smith $E_{\text {, }}$ Wiesmiller K, Riechelmann $\mathrm{H}$, et al. Longterm treatment with aspirin desensitization: a prospective clinical trial comparing 100 and $300 \mathrm{mg}$ aspirin daily. Allergy. 2008; 63: 1228-1234.

61. Forer B, Kivity S, Sade J, Landsberg R. Aspirin desensitization for ASA triad patients - a prospective study of the rhinologist's perspective. Rhinology. 2011; 49: 95-100.

62. Berges-Gimeno MP, Simon RA, Stevenson DD: Early effects of aspirin desensitization treatment in asthmatic patients with aspirin-exacerbated respiratory disease. Ann Allergy Asthma Immunol. 2003; 90: 338-341.

63. Williams AN, Simon RA, Woessner KM, Stevenson DD. The relationship between historical aspirin-induced asthma and severity of asthma induced during oral aspirin challenges. J Allergy Clin Immunol. 2007; 120: 273-277.

64. Stevenson DD. Aspirin sensitivity and desensitization for asthma and sinusitis. Curr Allergy Asthma Reports. 2009; 9: 155163.

65. Williams AN, Woessner KM. The clinical effectiveness of aspirin desensitization in chronic Rhinosinusitis. Curr Allergy Asthma Reports. 2008; 8: 245-252.

66. Patriarca G, Bellioni P, Nucera E, Schiavano D, Papa G, Schino G. et al. Intranasal treatment with lysine acetylsalicylate in patients with nasal polyposis. Ann Allergy. 1991; 67: 588-592.

67. Scadding GK, Hassab M, Darby YC, Lund $V J$, Freedman A. Intranasal lysine aspirin in recurrent nasal polyposis. Clin Otolaryngol Allied Sci. 1995; 20: 561-563.

68. Nucera E, Schiavino D, Milani A, Del Ninno M, Misuraca C, Buonomo A, et al. Effects of lysine-acetylsalicylate (LAS) treatment in nasal polyposis: two controlled long term prospective follow up studies. Thorax. 2000; 55: S75-S78.

69. Parikh AA, Scadding GK. Intranasal lysineaspirin in aspirin-sensitive nasal polyposis: a controlled trial. Laryngoscope. 2005; 115:
1385-1390.

70. Ogata N, Darby Y, Scadding G: Intranasal lysine-aspirin administration decreases polyp volume in patients with aspirin-intolerant asthma. J Laryngol Otol. 2007; 121: 1156-1160.

71. Slavin RG, Spector SL, Bernstein IL, Kaliner MA, Kennedy DW, Virant FS, et al. The diagnosis and management of sinusitis: a practice parameter update. J Allergy Clin Immunol. 2005; 116: S13-S47.

72. Fokkens W, Lund V, Mullol J, et al. European Position Paper on Rhinosinusitis and Nasal Polyps 2007. Rhinology. 2007; 45 (Suppl20): 1-139.

73. Fokkens W, Lund V, Mullol J, et al. European Position Paper on Rhinosinusitis and Nasal Polyps 2007. Rhinology. 2012; 50 (Suppl23): 1-298.

74. Lee JY, Simon RA. Does it make sense to "desens"? Aspirin desensitization in the treatment of chronic rhinosinusitis. Curr Allergy Asthma Reports. 2006; 6: 183-184.

75. Vaidyanathan S, McKean S, Lipworth BJ. Aspirin desensitisation therapy for aspirin-intolerant chronic rhinosinusitis. Cochrane Database of Systematic Reviews 2009, Issue 4. Art. No: CD008124. DOI:10.1002/14651858.CD008124.

76. NHS Economic Evaluation Database. Available at: http://www.crd.york. a c.uk/CRDWeb/ShowRecord. asp? $\mid \mathrm{D}=22008000223$

77. Hope AP, Woessner KA, Simon RA, Stevenson DD. Rational approach to aspirin dosing during oral challenges and desensitization of patients with aspirin-exacerbated respiratory disease. J Allergy Clin Immunol. 2008; 123: 406-410.

78. Williams AN, Simon RA, Woessner KM, Stevenson DD. The relationship between historical aspirin-induced asthma and severity of asthma induced during oral aspirin challenges. J Allergy Clin Immunol. 2007; 120: 273-277.

\section{James E Mitchell}

Department of Ear Nose and Throat

Surgery

Royal Surrey County Hospital,

Guildford, GU2 7XX

United Kingdom

Fax: +44-1483-408 377

E-mail: jamesmitchell@btopenworld. com 